\title{
VERTICAL TURBULENT EXCHANGE COEFFICIENT PARAMETRIZATION IN THE FRAMEWORK OF THE LES APPROACH*
}

\author{
S.V. Protsenko, A.M. Atayan \\ Don State Technical University, Rostov-on-Don, Russia \\ ■ rab55555@rambler.ru, atayan24@mail.ru
}

The vertical turbulent exchange coefficient parametrization based on the LES approach is constructed in this paper. To implement this approach, water flow velocities pulsations full-scale data at some points of shallowwater systems obtained using an acoustic Doppler flow meter (ADCP) during expedition studies were filtered using two-stage Kalman algorithm, and then averaged, after which the LES approach was applied using subgrid turbulence model. The parametrization of the coefficient of vertical turbulent exchange is used in the wave hydrodynamics mathematical model.

Keywords: vertical turbulent exchange coefficient, subgrid turbulence model, turbulent motion, modeling of large vortices, Kalman filter

Introduction. The term «model» in the turbulent motion description using the Navier-Stokes equations is understood as additional assumptions about the turbulent flow that allow calculating its average characteristics, with the addition of source and other terms or other «model» modifications. The task of developing a model is to set the type of modification of the Navier-Stokes equations that has a given accuracy and allows experimental verification (the type of equations, the method of calculating coefficients, etc.)

Turbulence modeling is one of the key elements in calculating flow dynamics. Turbulent flow is random process with wide range of time and spatial pulsation scales of all flow characteristics. Statistical approaches are used to describe turbulent flow, in particular, averaged characteristics are calculated and measured. Subgrid direct methods are based on the turbulent flows definition as the products of flow velocity components deviations and the transferred physical quantity averaged over space or time. For direct subgrid methods for estimating the vertical turbulence characteristics, there is a problem that requires large amounts of data in long and expensive expedition measurements.

Let's consider approaches to numerical turbulence modeling:

- DNS-direct numerical simulation is «model-free» numerical solution of the Navier-Stokes equations, free from assumptions, but satisfying the physical criteria for the suitability of computational grids and the quality requirements of approximation schemes. This criterion in DNS is an estimate of the minimum allowed grid size: $\mathrm{N} \sim \mathrm{Re}^{9 / 4}$;

- RANS-Reynolds averaged Navier-Stokes;

\footnotetext{
${ }^{*}$ The reported study was funded by RFBR according to the research project 20-31-90105.
} 
- «Algebraic models» - special case of RANS;

- LES-Large eddies simulation (versions: VLES, DES etc.) - Reynolds averaging is carried out taking into account the ripples distribution over frequencies, not including those that are resolved by grid partitioning, then you will get a blank for the LES model;

- «Transitional» models - RANS extensions for intermittent turbulence.

Statement of 3D wave hydrodynamics problem. The developed model for calculating 3D velocity vector of the aquatic environment movement based on is hydrodynamics mathematical model of shallow water bodies:

- the equation of motion (system of Navier-Stokes equations)

$$
\begin{gathered}
u_{t}^{\prime}+u u_{x}^{\prime}+v u_{y}^{\prime}+w u_{z}^{\prime}=-\frac{1}{\rho} P_{x}^{\prime}+\left(\mu u_{x}^{\prime}\right)_{x}^{\prime}+\left(\mu u_{y}^{\prime}\right)_{y}^{\prime}+\left(v u_{z}^{\prime}\right)_{z}^{\prime}, \\
v_{t}^{\prime}+u v_{x}^{\prime}+v v_{y}^{\prime}+w v_{z}^{\prime}=-\frac{1}{\rho} P_{y}^{\prime}+\left(\mu v_{x}^{\prime}\right)_{x}^{\prime}+\left(\mu v_{y}^{\prime}\right)_{y}^{\prime}+\left(v v_{z}^{\prime}\right)_{z}^{\prime}, \\
w_{t}^{\prime}+u w_{x}^{\prime}+v w_{y}^{\prime}+w w_{z}^{\prime}=-\frac{1}{\rho} P_{z}^{\prime}+\left(\mu w_{x}^{\prime}\right)_{x}^{\prime}+\left(\mu w_{y}^{\prime}\right)_{y}^{\prime}+\left(v w_{z}^{\prime}\right)_{z}^{\prime}+g,
\end{gathered}
$$

- continuity equation (mass conservation law)

$$
\rho_{t}^{\prime}+(\rho u)_{x}^{\prime}+(\rho v)_{y}^{\prime}+(\rho w)_{z}^{\prime}=0,
$$

where $\mathbf{V}=\{u, v, w\}$ is the water flow of shallow water body velocity vector; $P$ is the hydrodynamic pressure; $\rho$ is the aquatic environment density; $\mu, v$ are turbulent exchange coefficients in the horizontal and vertical directions; $g$ is the gravity acceleration.

The system of equations for the movement of the aquatic environment is considered under the following initial condition $\mathbf{V}=\mathbf{V}_{0}$ and boundary conditions:

-entrance (incoming streams from the sea and in the riverbed) $\mathbf{V}=\mathbf{V}_{0}, P_{\mathbf{n}}^{\prime}=0$,

- lateral and lower water-bottom boundary $\rho_{v} \mu\left(\mathbf{V}_{\tau}\right)_{\mathbf{n}}^{\prime}=-\boldsymbol{\tau}, \mathbf{V}_{\mathbf{n}}=0, P_{\mathbf{n}}^{\prime}=0$,

- lateral boundary $\left(\mathbf{V}_{\tau}\right)^{\prime}=0, \mathbf{V}_{\mathbf{n}}^{\prime}=0, P_{\mathbf{n}}^{\prime}=0$,

- water surface (water-air boundary) $\rho_{v} \mu\left(\mathbf{V}_{\boldsymbol{\tau}}\right)_{\mathbf{n}}^{\prime}=-\boldsymbol{\tau}, w=-P_{t}^{\prime} / \rho g, P_{\mathbf{n}}^{\prime}=0$,

where $\mathbf{V}_{\mathbf{n}}, \mathbf{V}_{\tau}$ are the velocity vector normal and tangential component; $\mathbf{n}$ is the normal vector; $\boldsymbol{\tau}=\left\{\tau_{x}, \tau_{y}, \tau_{z}\right\}$ is the tangential stress vector; $\rho_{v}$ is suspension density.

On the free surface of a water body, the tangential stress is calculated as follows $\boldsymbol{\tau}=\rho_{a} C d_{s}|\mathbf{w}| \mathbf{w}$, where $\mathbf{w}$ is the wind velocity relative to water; $\rho_{a}$ is the atmosphere density; $C d_{s}=0,0026$ is the dimensionless surface resistance coefficient, which depends on wind speed.

At the water body's bottom, the tangential stress has the form $\boldsymbol{\tau}=\rho C d_{b}|\mathbf{V}| \mathbf{V}$, where $C d_{b}=g k^{2} / h^{1 / 3}$, is the group roughness coefficient in Manning's formula; $h$ is the distance from free surface to bottom. 
Turbulent exchange modeling based on the water flow velocity profiles field observations in shallow water body. Large eddies simulation (LES) assumes that large eddies receive energy from the averaged flow, the structure of large eddies significantly depends on the considered flow, small eddies receive energy through cascade transport, and their structure is much more universal. Modeling small eddies is much more promising than modeling large ones. The filtering procedure allows to separate large vortices from small ones. The filtered equations are closed using a «subgrid» turbulence model. Vortices whose size is smaller than the filter size $\Delta$ are modeled. The filter size $\Delta$ is explicitly included in the model. Often, in practice, they don't use explicit filters. The size of the grid cell plays the role of the filter.

The subgrid model explicitly contains the grid cell size, vortices that are smaller than the grid cell size are naturally filtered out, and for accurate resolution of vortices that are not much larger than the cell size, it is necessary to use modern low-dissipative schemes.

Table 1. Coordinates and data of stations

\begin{tabular}{|c|c|c|c|}
\hline Station, no. & \multicolumn{2}{|l|}{ Station data } & $\begin{array}{l}\text { Coordinates } \\
\text { SH / VD } \\
\text { yy-mm, m }\end{array}$ \\
\hline $1(49)$ & $\begin{array}{l}\text { Transparency }-3 \mathrm{~m}, \\
\text { Air temperature } 25.6^{\circ} \mathrm{C} \\
\text { Water temperature } 25.8^{\circ} \mathrm{C} \\
\text { Wind SW Sunny } \\
\text { Depth } 11.5 \mathrm{~m}\end{array}$ & $\begin{array}{l}\text { Wind speed } 3 \mathrm{~m} / \mathrm{s} \text {, SW direction } \\
138^{\circ} \\
\text { Humidity } 83 \% \text {, pressure } 1008\end{array}$ & $\begin{array}{l}46^{\circ} 39.6^{\prime} \\
37^{\circ} 20.7^{\prime}\end{array}$ \\
\hline $2\left(48^{\prime}\right)$ & $\begin{array}{l}\text { Transparency }-2.3 \mathrm{~m}, \\
\text { Air temperature } 26.3^{\circ} \mathrm{C} \\
\text { Water temperature } 27.6^{\circ} \mathrm{C} \\
\text { Depth } 12 \mathrm{~m}\end{array}$ & $\begin{array}{l}\text { Wind speed } 2.7 \mathrm{~m} / \mathrm{s} \text {, direction } \mathrm{U} \\
185^{\circ} \\
\text { Humidity } 75 \% \text {, pressure } 1008,6\end{array}$ & $\begin{array}{l}46^{\circ} 29.7^{\prime} \\
36^{\circ} 59.76^{\prime}\end{array}$ \\
\hline $3\left(44^{\prime}\right)$ & $\begin{array}{l}\text { Transparency }-2 \mathrm{~m}, \\
\text { Air temperature } 27.1^{\circ} \mathrm{C} \\
\text { Water temperature } 26.8^{\circ} \mathrm{C} \\
\text { Depth } 12 \mathrm{~m}\end{array}$ & $\begin{array}{l}\text { Wind speed } 0.8 \mathrm{~m} / \mathrm{s}, \quad \text { low } \\
\text { confidence } \\
\text { Humidity } 66 \% \text {, pressure } 1008,6\end{array}$ & $\begin{array}{l}46^{\circ} 19.68^{\prime} \\
36^{\circ} 59.76^{\prime}\end{array}$ \\
\hline 4 (44') & $\begin{array}{l}\text { Transparency }-2.5 \mathrm{~m}, \\
\text { Air temperature } 28^{\circ} \mathrm{C} \\
\text { Water temperature } 27.3^{\circ} \mathrm{C} \\
\text { Depth } 10 \mathrm{~m}\end{array}$ & $\begin{array}{l}\text { Wind speed } 65^{\circ}-70^{\circ} \text {, calm, SW, } \\
\text { sunny } \\
\text { Humidity } 65 \% \text {, pressure } 1007,9\end{array}$ & $\begin{array}{l}46^{\circ} 9.66^{\prime} \\
36^{\circ} 59.76^{\prime}\end{array}$ \\
\hline $5(41)$ & $\begin{array}{l}\text { Air temperature } 28^{\circ} \mathrm{C} \\
\text { Water temperature } 27.4^{\circ} \mathrm{C} \\
\text { Depth } 12.5 \mathrm{~m}\end{array}$ & $\begin{array}{l}\text { Wind speed } 54^{\circ}-59^{\circ} \text {, calm } \\
\text { Humidity } 64 \% \text {, pressure } 1007,4\end{array}$ & $\begin{array}{l}46^{\circ} 0.06^{\prime} \\
36^{\circ} 59.76^{\prime}\end{array}$ \\
\hline $6(36)$ & $\begin{array}{l}\text { Transparency }-3.5 \mathrm{~m}, \\
\text { Air temperature } 26.8^{\circ} \mathrm{C} \\
\text { Water temperature } 27.3^{\circ} \mathrm{C} \\
\text { Depth } 11 \mathrm{~m}\end{array}$ & $\begin{array}{l}\text { Wind speed } 70-80^{\circ}-80^{\circ} .5 \mathrm{~m} / \mathrm{s} \\
\text { Humidity } 80 \% \text {, pressure } 1007.4\end{array}$ & $\begin{array}{l}45^{\circ} 43.5^{\prime} \\
36^{\circ} 51.54^{\prime}\end{array}$ \\
\hline
\end{tabular}

The measurements were carried out vertically, starting from the near sensitivity zone of the ADCP probe to the bottom. The profiler operates on the Doppler effect, transmitting an acoustic signal at a fixed frequency and receiving the signal reflected on the inhomogeneities of the water medium in the water column thickness located under the emitter. The influence of changes in the values of the vertical turbulent exchange coefficient on the content of dissolved oxygen in the bottom 
layer of a shallow reservoir is studied. Approximately at a depth of 3 meters and below, the values of the vertical turbulent exchange coefficient are close to zero, which means a reduced vertical turbulent exchange in this area, and explains the phenomenon of hypoxia in the bottom layer of the CentralEastern part of the Azov Sea during the summer period. As input data for solving the filtration problem, the initial data on the flow rates of the water medium flow are received. The initial data for solving this problem are: the number of depth resolution elements was 128, the depth measurement step was $10 \mathrm{~cm}$, the measurement period was $1 \mathrm{~s}$, and the number of measurements at each station varied from 200 to 1000 .

The two-stage Kalman algorithm was used to construct filtering model. The Kalman filter algorithm is based on the equations of state

$$
x_{k}=F x_{k-1}+B u_{k-1}+w_{k-1}, \quad z_{k}=H x_{k}+v_{k},
$$

where $x_{k}$ is the state vector containing the variables of the dynamic system at time $k ; u_{k}$ is the vector containing the control inputs; $F$ - matrix that describes the state change of the system; $B$ management matrix for the vector of influence $u_{k} ; w_{k}$ is the vector containing the noise process and a specified covariance matrix $Q ; z_{k}$ - vector changes; $H$ - transform; $v_{k}$ - vector contains the changes of the noise for each observation vector changes with the covariance matrix $R$.

The corresponding estimation errors are determined based on the state estimates:

$$
e_{k}^{-} \equiv x_{k}-\hat{x}_{k}^{-}, \quad e_{k} \equiv x_{k}-\hat{x}_{k},
$$

where $e_{k}^{-}$is the a priori estimation error, and $e_{k}$ is the a posteriori estimation error.

The posteriori estimation equation $\hat{x}_{k}$ is described as linear combination of the priori estimate $\hat{x}_{k}^{-}$and the difference between the actual measurement $z_{k}$ and the forecast of the measurement $H \hat{x}_{k}^{-}$

$$
\widehat{x}_{k}=\widehat{x}_{k}^{-}+K_{k}\left(z_{k}-H \widehat{x}_{k}^{-}\right) \text {, }
$$

where $K_{k}$ is the dimension gain matrix required to minimize the posterior covariance error.

Find the gain matrix $K_{k}$ values as follows:

$$
K_{k}=P_{k}^{-} H^{T}\left(H P_{k}^{-} H^{T}+R\right)^{-1}
$$

where $P_{k}^{-}=E\left[e_{k}^{-} e_{k}^{-T}\right]$ is the priori error covariance matrix.

The second stage is responsible for refining the result calculated during the prediction phase using the corresponding field measurements obtained probably with some error, and on their basis the forecast is corrected using the measurement update equations.

The coefficients of the covariance matrices $\mathrm{R}$ and $\mathrm{Q}$ were selected in a special way: R-based on the measurement error of the device (standard deviation), Q - based on the required filtration level.

Typically, when implementing a filter, the measurement noise covariance is determined before applying the filter. Measuring the covariance of the measurement noise error is mostly considered a practical task, since at any time you need to be ready to measure the current state of the process. 

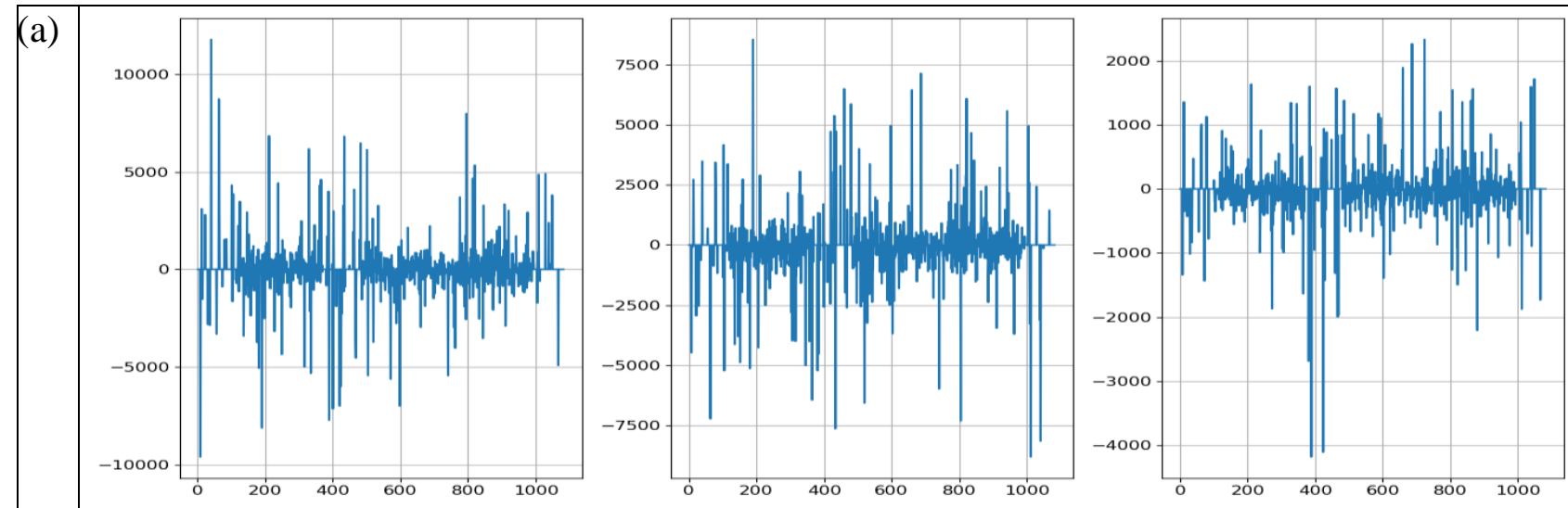

(b)
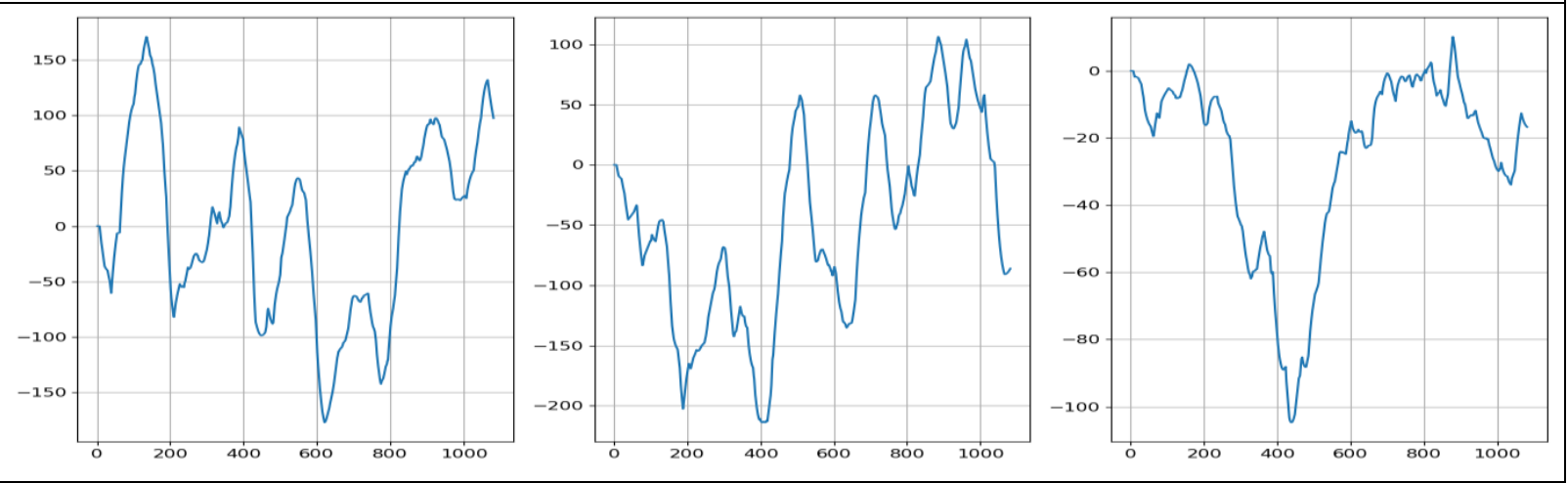

Fig. 1. Applying Kalman filter to eliminate data noise

(a) initial data with measurement device error,

(b) data obtained after applying the filtering algorithm

Fig. 1 shows an example of the operation of software designed to eliminate noise from the measured expedition data of the water flow velocity field. By applying the Kalman filter, the data spread and oscillation amplitude are noticeably reduced, which in turn allows a more adequate assessment of the information obtained during field experiments. When adapting to a specific task, the Kalman filter can be used to reduce the noise of field data of the water flow velocity field.

Fig. 2 shows an example of the operation of software designed to eliminate the noise level of expedition measurements of one of the components of the water flow velocity vector. The vertical axis shows the depth of the reservoir, and the horizontal axis shows the time. Fig. 2 shows the color indicates the water flow rate in $\mathrm{mm} / \mathrm{sec}$ according to the scale.

Parametrization of the turbulent exchange process in discrete models, primarily for the vertical coordinate direction, is performed taking into account the density gradient of the water medium based on modern subgrid models. To parameterize the vertical turbulent exchange coefficient, we consider algebraic subgrid models based on the definition of turbulent flows as the products of deviations of the components of the flow velocity and the transferred physical quantity averaged over space or time. 


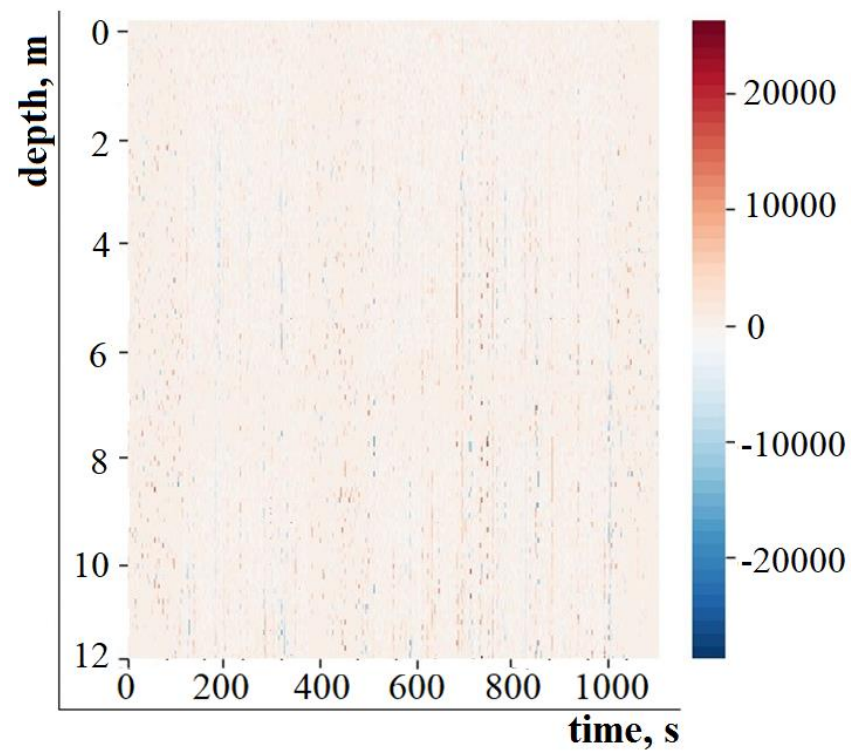

(a)

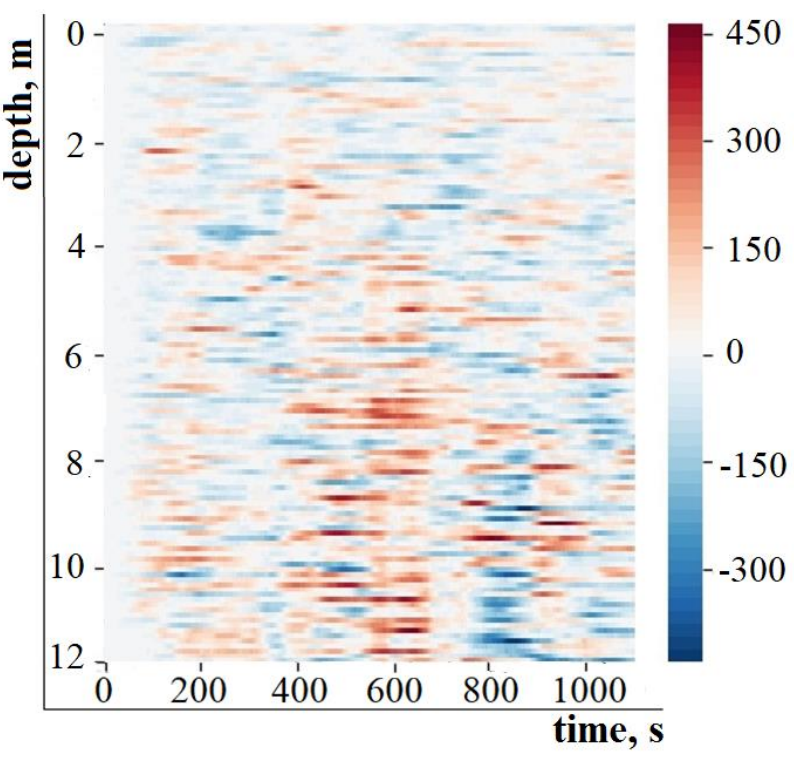

(b)

Fig. 2. Applying Kalman filter to eliminate data noise in the two-dimensional case

(a) initial data with measurement device error,

(b) data obtained after applying the filtering algorithm

Experiments were performed based on several approaches for calculating the vertical turbulent exchange coefficient:

1. Parametrization of Belotserkovsky $v=(C \Delta z)\left[\left(\frac{\partial \bar{u}}{\partial z}\right)^{2}+\left(\frac{\partial \bar{v}}{\partial z}\right)^{2}\right]$.

2. Boussinesq parameterization $v=(0,41 z)^{2} 0,5 \sqrt{\left(\frac{\partial \bar{u}}{\partial z}\right)^{2}+\left(\frac{\partial \bar{v}}{\partial z}\right)^{2}}$.

3. Smagorinsky parameterization $v=0,5(C \Delta)^{2} \sqrt{\left(\frac{\partial \bar{u}}{\partial z}\right)^{2}+\left(\frac{\partial \bar{v}}{\partial z}\right)^{2}}$,

where $v$ is the coefficient of turbulent exchange in the vertical direction; $\bar{u}, \bar{v}$ are the components of the water flow velocity averaged over the time of pulsation in the horizontal direction, $C$ is dimensionless empirical constant; $\Delta$ is characteristic scale of the grid.

The change in turbulence modeling technologies is driven by the exponential growth of available computing resources that has been observed in recent decades. Depending on which processes are dominant in the vertical direction, different models of vertical turbulent exchange are used. Thus, on the basis of the considered methods for calculating the vertical turbulent exchange coefficient, distributions that are inhomogeneous vertically for all measurement points are obtained.

Comparative analysis of the vertical turbulent exchange coefficient obtained distributions results showed that the results of parameterization based on all models show similar results in order of magnitude, as well as in the location of peaks on the graphs. The phenomenon of sharp jumps in the coefficient on all graphs is associated with errors in the measurements of the pulsations of the vertical velocity component, which is included in the calculation formula of the method. 


\begin{tabular}{|c|c|c|c|}
\hline Station data & P Belotserkovsky & P Bussineska & P Smagorinsky \\
\hline $\begin{array}{l}\text { Station \# } 1(49) \\
\text { Transparency - } 3 \mathrm{~m}, \\
\mathrm{~T} \text { air } 25.6^{\circ} \mathrm{S} \\
\mathrm{T} \text { water } 25.8^{\circ} \mathrm{S} \\
\text { Depth } 11.5 \mathrm{~m} \\
\text { Wind speed } 3 \mathrm{~m} / \mathrm{s}, \mathrm{SW} \\
\text { direction } 138^{\circ} \\
\text { Coordinates } 46^{\circ} \quad 39 \text {, } \\
569^{\prime} \mathrm{N} 37^{\circ} 20,743^{\prime} \mathrm{E}\end{array}$ & " & $=$ & " \\
\hline $\begin{array}{l}\text { Station \# } 2\left(48^{\prime}\right) \\
\text { Transparency-2.3 m, } \\
\text { T air } 26.3^{\circ} \mathrm{S} \\
\text { T water } 27.6^{\circ} \mathrm{S} \\
\text { Depth } 12 \mathrm{~m} \\
\text { Wind speed } 2.7 \mathrm{~m} / \mathrm{s} \\
\text { Coordinates } 46^{\circ} 29, \\
725^{\prime} \mathrm{N} 36^{\circ} 59,786^{\prime} \mathrm{E}\end{array}$ & & & (1) \\
\hline $\begin{array}{l}\text { Station \# } 3\left(44^{\prime}\right) \\
\text { Transparency - } 2 \mathrm{~m}, \\
\text { T air } 27.1^{\circ} \mathrm{S} \\
\text { T water } 26.8^{\circ} \mathrm{S} \\
\text { Depth } 12 \mathrm{~m} \\
\text { Wind speed } 0.8 \mathrm{~m} / \mathrm{s} \text {, } \\
\text { low confidence } \\
\text { Coordinates } 46^{\circ} \quad 19 \text {, } \\
693^{\prime} \mathrm{N} 36^{\circ} 59,683^{\prime} \mathrm{E}\end{array}$ & of & & $\begin{array}{l}5= \\
=-5 \\
3=5 \\
=5\end{array}$ \\
\hline $\begin{array}{l}\text { Station \# } 4\left(44^{\prime \prime}\right) \\
\text { Transparency-2.5 m, } \\
\text { T air } 28^{\circ} \mathrm{S} \\
\text { T water } 27.3^{\circ} \mathrm{S} \\
\text { Depth } 10 \mathrm{~m} \\
\text { Coordinates } 46^{\circ} \quad 09 \text {, } \\
670^{\prime} \mathrm{N} 36^{\circ} 59,756^{\prime} \mathrm{E}\end{array}$ & & & 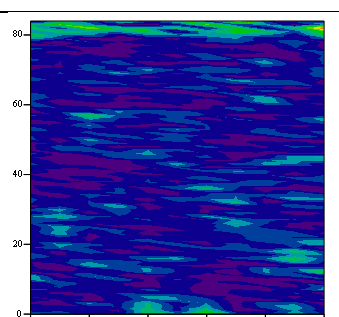 \\
\hline $\begin{array}{l}\text { Station \# } 5(41) \\
\mathrm{T} \text { air } 28^{\circ} \mathrm{S} \\
\mathrm{T} \text { water } 27.4^{\circ} \mathrm{S} \\
\text { Depth } 12.5 \mathrm{~m} \\
\text { Wind speed } 54^{\circ}-59^{\circ} \text {, } \\
\text { calm } \\
\text { Coordinates } 46^{\circ} \quad 00 \text {, } \\
036^{\prime} \mathrm{N} 36^{\circ} 59,762^{\prime} \mathrm{E}\end{array}$ & & $E$ & $\begin{array}{l}=2-1 \\
=\end{array}$ \\
\hline $\begin{array}{l}\text { Station \# } 6(36) \\
\text { Transparency-3.5 m, } \\
\text { T air } 26.8^{\circ} \mathrm{S} \\
\text { T water } 27.3^{\circ} \mathrm{S} \\
\text { Depth } 11 \mathrm{~m} \\
\text { Wind speed } 70-80^{\circ}- \\
80^{\circ} .5 \mathrm{~m} / \mathrm{s} \\
\text { Coordinates } 45^{\circ} \quad 43 \text {, } \\
491^{\prime} \mathrm{N} 36^{\circ} 51,494^{\prime} \mathrm{E}\end{array}$ & $\overline{-}$ & + & $\begin{array}{c}=-\square= \\
=-1\end{array}$ \\
\hline
\end{tabular}

Fig. 3. Results of calculating the turbulent exchange coefficient 

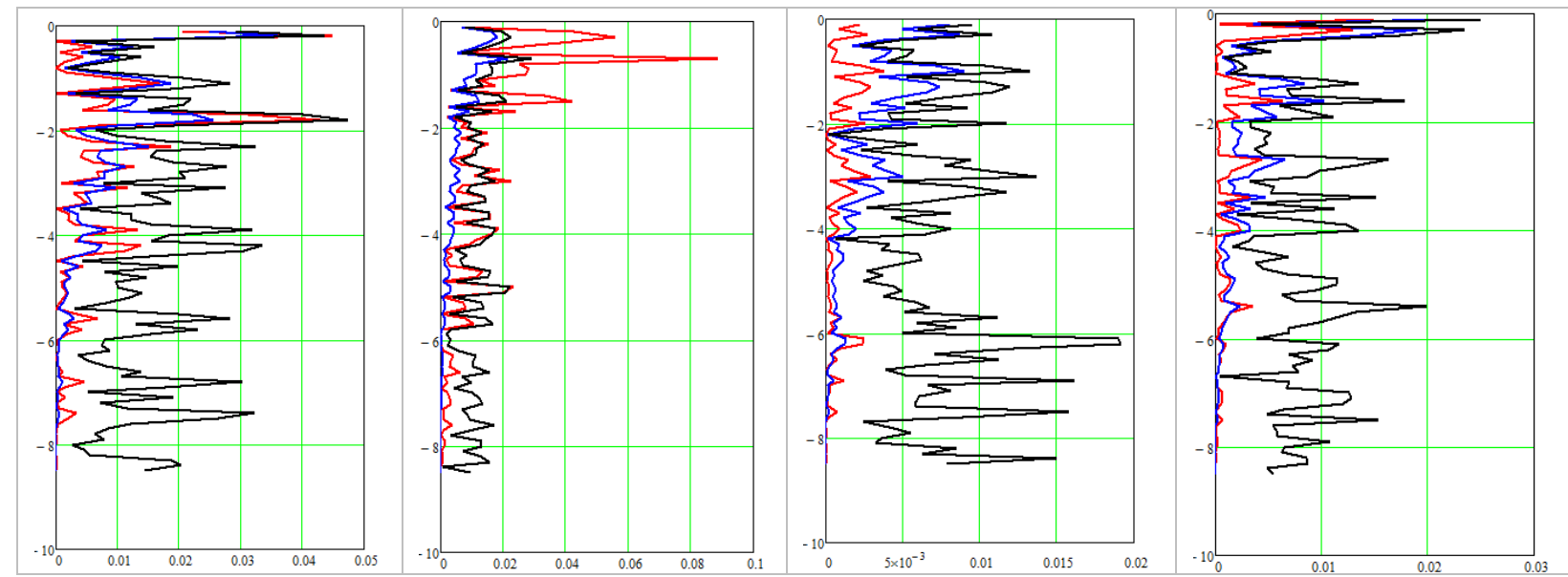

Fig. 4. The vertical turbulent exchange coefficient at points (the red line is the Belotserkovsky parametrization, the blue line is Boussinesq, the black line is Smagorinsky)

The presence of errors in the measurements of the pulsations of the vertical velocity component is associated with many phenomena occurring at the time of measurement, such as ship deviation, fluctuations in the free surface, changes in depth, stability, wind and waves.

The profiles of the coefficient of vertical turbulent exchange at a time show that the parametrization of Belotserkovsky and Boussinesq most adequately reflects the processes of turbulent exchange for shallow water bodies, but to assess the quality of parametrization, a more in-depth analysis using mathematical statistics methods is necessary.

Conclusion. Chaotic velocity fluctuations in the vertical direction largely determine all hydrodynamic processes in shallow water bodies. There is a need for the most accurate calculation of the wave field pattern in order to predict phenomena that are inhomogeneous vertically, and a constant coefficient of vertical turbulent exchange cannot give the necessary accuracy, which proves the need for modeling turbulent exchange based on processing data from field observations of water flow velocity profiles in a number of applied problems. The principal advantage of LES is that, due to the relative uniformity and isotropy of small-scale turbulence, the description of its characteristics using a subgrid model is much more accurate than modeling the entire spectrum of turbulent pulsations. The main reason for this is that large structures often turn out to be insufficiently random, in which case it is not fully justified to use statistical moments to describe their properties, these values are modeled within the framework of such approaches.

\section{References}

1. Abalakin, I. V. Using an algebraic turbulence model for calculating non-stationary flows in the vicinity of recesses / I. V. Abalakin, A. N. Antonov, I. A. Graur, B. N. Chetverushkin // Mathematical modeling. 2000. - Vol. 12, No. 1. - pp. 45-56.

2. Alekseenko, E. V. Comparative analysis of classical and non-classical models of hydrodynamics of reservoirs with turbulent exchange / E. V. Alekseenko, O. V. Kolgunova, B. V. Sidorenko, A. E. Chistyakov / / Izvestiya SFU. Technical sciences. Thematic issue: Actual problems of mathematical modeling. - Taganrog: publishing house of TTI SFU, 2009. - Vol. 97. - No. 8. - pp. 6-18.

3. Belotserkovsky O. M., Oparin A.M., Chechetkin V. M. Turbulence. New approaches. - Moscow: Nauka, 2002. 
4. Chistyakov A.E., Protsenko S.V. The investigation of turbulent exchange by methods of stochastic analysis // Theory of Probability and its Applications. - 2019. - Vol. 64.

5. Colombini M., Stocchino A. Wind effect in turbulence parameterization // ELSEVIER - Advances in Water Resources, 2005.

6. George L. Mellor Development of a Turbulence Closure Model for Geophysical Fluid Problems // Reviews of geophysics. - Vol. 20, № 4. - 1982. - pp. 851-875.

7. Jie Cui, Virendra C. Patel, Ching-Long Lin Large-eddy simulation of turbulent flow in a channel with rib roughness //ELSEVIER - Heat and fluid flow, 2003.

8. Sukhinov A.I., Chistyakov A.E., Alekseenko E.V. Numerical realization of the three-dimensional model of hydrodynamics for shallow water basins on a high-performance system // Mathematical Models and Computer Simulations. - 2011. - T. 3, № 5. - C. 562-574.

9. Sukhinov A.I., Chistyakov A.E., Protsenko E.A., Sidoryakina V.V., Protsenko S.V. Three-dimensional mathematical model of propagation of waves towards the shore // Communications in Computer and Information Science. - 2018 - Vol. 910. - P. 322-335. DOI: 10.1007/978-3-319-99673-8_23.

10. WinADCP User's Guide RD Instruments Acoustic Doppler Solutions, P/N 957-6158-00.

\section{Authors:}

Protsenko Sofya, Don State Technical University, (Gagarin square, 1, Rostov-on-Don, Russia), Postgraduate student of the Department of Mathematics and Informatics, Junior Researcher of the Department of Scientific Research, DSTU. Email address: rab55555@rambler.ru

Atayan Asya, Don State Technical University, (Gagarin square, 1, Rostov-on-Don, Russia), Postgraduate student of the Department of Mathematics and Informatics, Junior Researcher of the Department of Scientific Research, DSTU. Email address: atayan24@mail.ru 


\section{ПАРАМЕТРИЗАЦИЯ КОЭФФИЦИЕНТА ВЕРТИКАЛЬНОГО ТУРБУЛЕНТНОГО ОБМЕНА В РАМКАХ ПОДХОДА LЕS*}

\section{С.В. Проценко, А.М. Атаян}

Донской государственный технический университет, Ростов-на-Дону, Российская Федерация

๑rab55555@rambler.ru, atayan24@mail.ru

В работе построена параметризация коэффициент вертикального турбулентного обмена на основе подхода LES. Для реализации данного подхода натурные данные о пульсациях скоростей водного потока в некоторых точках мелководных систем, полученные с помощью акустического доплеровского измерителя течений (ADCP) во время экспедиционных исследований, отфильтрованы с помощью двухэтапного алгоритма Калмана, а затем усреднены, после чего при помощи «подсеточной» модели турбулентности применен подход LES. Параметризация коэффициент вертикального турбулентного обмена используется в дальнейшем в математической модели волновой гидродинамики.

Ключевые слова: коэффициент вертикального турбулентного обмена, подсеточная модель турбулентности, турбулентное движение, моделирование больших вихрей, фильтр Калмана

\section{Авторы:}

Проценко Софья Владимировна, Донской государственный технический университет (344000, Ростов-на-Дону, пл. Гагарина, 1), аспирант кафедры «Математика и информатика», младший научный сотрудник УНИ ДГТУ, rab55555@rambler.ru

Атаян Ася Михайловна, Донской государственный технический университет (344000, Ростов-на-Дону, пл. Гагарина, 1), аспирант кафедры «Математика и информатика», младший научный сотрудник УНИ ДГТУ, atayan24@mail.ru

\footnotetext{
* Исследование выполнено при финансовой поддержке РФФИ в рамках научного проекта № 20-31-90105.
} 